\title{
Breast Cancer Incidence by Age at Finding of Mammographic Abnormality in Women Participating in French Organized Screening Campaigns.
}

AKOÏ KOIIVOGUI ( $\nabla$ aakoivogui@live.fr)

COMITE DEPARTEMENTAL DES CANCERS https://orcid.org/0000-0001-9097-3006

CHRISTIAN BALAMOU

CRCDC-AURA

Raushan RYMZHANOVA

CRCDC-BOURGOGNE-FRANCHE-COMTE

STEPHANE CORNELIS

CRCDC-BOURGOGNE-FRANCHE-COMTE

CHRISTELLE RODRIGUE-MOULINIE

CRCDC-AURA

NICOLAS SELLIER

APHP: Assistance Publique - Hopitaux de Paris

\section{Research Article}

Keywords: Breast cancer screening, Mammography, Mammographic abnormality, Breast cancer incidence

Posted Date: February 9th, 2021

DOl: https://doi.org/10.21203/rs.3.rs-185428/v1

License: (c) (i) This work is licensed under a Creative Commons Attribution 4.0 International License. Read Full License 


\section{Abstract}

Purpose: Using reduced samples, statistical modelling was already predicted the occurrence of Breast-cancer or its prognosis from previous radiological findings. This study aims to predict breast-cancer risk by mammographic abnormalities finding age in the French breast-cancer screening campaign.

Methods: The study involved 261,083 women aged 50-74 living in French Departments (Ain, Doubs, Haute-Saône, Jura, Territoire-de-Belfort, Yonne). These women had at least two screening mammograms between Jan-1999 and Dec-2017 of which the first was classified as "normal/benign". The incidence of mammographic-abnormality (microcalcification, spiculated-mass, obscured-mass, architectural-distortion, asymmetric-density) and the incidence of breast-cancer after abnormality detection were estimated abnormalities finding age, using an actuarial life-table method. Breast-cancer risk was predicted in a Cox multivariate model.

Results: The incidence of mammographic-abnormality was $95.4[94.9 ; 95.9] / 1000$ person-years. Breast-cancer (6,326 cases) incidence was 3.3[3.0; 3.1]/1000 person-years. That incidence was 5 times higher in women who showed a speculated-mass vs. those who did not $(6.9[6.4 ; 7.4]$ vs. $1.3[1.2 ; 1.3])$. Whatever the abnormality, the incidence of cancer was higher when it was present in only one breast. Depending on the spiculated-mass finding age, the risk increased by at least $40 \%$ between the age groups 55-59years $(1.4[1.0 ; 1.8])$ and $\geq 70 y e a r s ~(2.4[1.9 ; 3.3])$.

Conclusion: The study showed the increased risk of cancer with the abnormalities finding age and the low risk related to the presence of the same mammographic-abnormality in both breasts compared to the isolated mammographic-abnormality in one of the breasts. This should alert radiologists to the relevance of certain diagnostic procedures in the management of a bilateral mammographic abnormality.

\section{Introduction}

Breast cancer (B-cancer) is the world's most common and severe cancer in women: it would be responsible for $11.6 \%$ of cancers and $6.6 \%$ of deaths from cancer in women [1]. As other European countries, France has been offering a national organized Bcancer screening program (BCSP) since 2004 [2, 3]. The BCSP targets women aged 50-74 years old with no other risk factor than age and offer them a clinical breast examination and a mammography screening by a licensed radiologist once every two years [2, 4]. All mammograms considered as normal or benign in a first reading seance are submitted to a second reading whether or not an immediate diagnostic assessment has been carried out[3].

To distinguish between a benign and malign breast lesions, the radiologists use the Breast Imaging Reporting System and Data System (BIRADS) classification [5]. The radiological findings that support this classification are indicative of certain forms or locations of B-cancer [6-11]. Breast microcalcifications are present in about $30 \%$ of all malignant breast lesions, in over half of the malignant infraclinical breast lesions, and lead to depict $85-95 \%$ of all cases of ductal carcinoma in situ in screening campaigns [10]. The positive predictive value of malignancy varies according to the mass contour [6]. Although there are several other risk factors $[7,12,13]$, it is established that B-cancer can occur without apparent mammographic finding, especially in the case of radiologically dense breasts[14].

Statistical modelling was already predicted the occurrence of B-cancer or its prognosis from previous radiological findings. A few studies converged towards a positive association between the risk score calculated on previous mammograms and imagedetected B-cancer at screening mammograms [15-18]. In addition to the reduced sample size, these studies did not describe the B-cancer risk according to the finding age of each radiological abnormality.

To optimize the interpretation of these mammographic abnormalities in the daily practice of radiologists, the contribution of artificial intelligence and deep-learning is increasingly emphasized [19-23]. Certainly, if there is one field of medicine in which artificial intelligence will offer many advances, it is of course, the fields of prevention and screening [24]. However, despite the significant contribution of these new technologies, the conventional reading of mammograms by radiologists is still essential $[19,25]$. In addition to the discussion on their ethical and legal aspects [26], there is no algorithm that has beyond doubt been 
proven to outperform double reporting by two certified breast radiologists [19]. To develop other more efficient algorithms, large databases are required $[21,22]$.

Pending the availability of such algorithms, the present study intends to alert radiologists by predicting B-cancer risk by mammographic abnormalities finding age.

\section{Methods}

\section{Study context}

The study consisted of a follow-up of 261,083 women, aged 50 to 74 years, living in six French Departments (Ain, Doubs, HauteSaône, Jura, Territoire-de-Belfort, Yonne). These women have at least two screening mammograms between 1999/01/01 and 2017/12/31 of which the first was considered as "normal/benign".

The study excluded women with less than two participations in the $\operatorname{BCSP}(90,274$ out of 351,357$)$. Were also excluded women with diagnosis of B-cancer at their first participation (3,417 out of 9,743 women who had at least one cancer during the study period). In fact, in these six Departments, women are still able to participate in the BCSP after a diagnosis of B-cancer during a previous campaign.

The mammographic abnormalities studied were: microcalcifications, spiculated-mass, obscured-mass, architectural-distortion and asymmetric-density. The definitions of these mammographic abnormalities are standardized in the BCSP. However, the study retained the description of microcalcification only if an immediate (or deferred) diagnostic workup confirmed the presence of microcalcification. The incidence of each mammographic abnormality has been described, subsequently, the B-cancer incidence has been described according to each mammographic abnormality finding age.

\section{BCSP organization}

In the six departments, BCSP management structures (BCSP-structure) were in charge, the organization of screening campaigns in accordance with BCSP specifications [3,5]. Before each campaign, a list of women was established and updated according to information from Health Insurance Plans. These women were invited by regular mail at their 50th birthday (first invitation) and then every two years after a negative mammogram (subsequent invitation) until the age of 74 years. The letter of invitation allows each woman to have a mammogram (two frontal and two oblique external incidences) in one of the radiological centers approved by the BCSP.

In each radiological center, the first reading of a mammogram was performed on a hard copy or a screen display. The radiologist first reader had also to collect sociodemographic, clinical, and radiological information on a standardized form. Using the printed films, the second reading, or even a third consensual or expert reading, was carried out in the BCSP-structure.

\section{Data collection}

The data analysed were extracted from the databases of the BCSP-structure. These databases were regularly enriched with sociodemographic, diagnostic, and follow-up data provided by radiologists, pathologists, oncologists, surgeons, gynecologists, general practitioners, health insurance plan, or medico-administrative databases.

The study distinguished the follow-up of the left breast from that of the right breast. The end date of follow-up (end-date) was the date of the last mammogram. Women aged <73 years were considered "lost to follow-up" whenever the date of the last mammogram was before 2015 because they could have had another mammogram before age 74 . The end of follow-up criterion was the diagnosis of a B-cancer lesion.

Regarding B-cancer diagnosis, the study adopted the $\mathrm{C} 50$ code of the $10^{\text {th }}$ version of the WHO International Classification of Diseases (ICD-10) [27] : i) ductal carcinoma in situ, lobular carcinoma in situ, and nipple Paget's disease were classified as "adenocarcinoma in situ" (TIS); ii) infiltrating/invasive ductal or lobular carcinomas were classified as "infiltrating 
adenocarcinoma" (ADK-I); and, iii) all other malignant tumors (papillary, tubular, mucinous, medullary, etc.) were classified as "rare form". Were considered first reading cancers (Cancer-R1), when the diagnostic process was started after a positive first mammographic reading (ACR in 0,3,4,5). Were considered second reading cancers (Cancer-R2), when the diagnostic process was started after a positive mammographic second reading (ACR in $0,3,4,5)$ following a negative first reading $(A C R$ in 1,2$)$. Interval breast cancers were those detected in the interim between regular screening examinations.

\section{Campaign dynamics}

For the analysis of the incidence of each mammographic abnormality, the follow-up started date was the date of the first screening mammogram. For each breast, this follow-up was censored at the abnormality finding date or at the study end-date if absence of abnormality.

In the B-cancer incidence analysis, the follow-up started date was the date of the first screening mammogram and this follow-up was censored at the end-date in the absence of B-cancer or at the date of the mammogram that triggered a B-cancer diagnostic procedure (date of B-cancer occurrencein the examined breast. In case of interval B-cancer, the follow-up was censored at the date of interval B-cancer diagnosis. The follow-up was censored at the end-date in all other cases, e.g., loss to follow-up, relocation, refusal to participate in BCSP, age $>74$ years, or death from causes other than B-cancer.

\section{Factors studied}

The factors were: i) the age at finding of each abnormality (in five categories: 50-54, 55-59, 60-64, 65-69, and 70-74 years); ii) the presence of each abnormality in the contralateral breast if it's present in the examined breast (in five categories: absence of the abnormality in the examined breast "NA", absence of the abnormality in the contralateral breast while it's present in the examined breast "Absent", presence of abnormality in the contralateral breast before its presence in the examined breast "Anterior", presence of abnormality in both breasts at the same date "Same_date", presence of abnormality in the contralateral breast after its presence in the examined breast "Posterior"); iii) the initial concomitance (associated abnormalities seen immediately on the same date) or posterior concomitance (abnormalities in successive association over time) of $\geq 2$ mammographic abnormalities in the examined breast (no abnormality "NA", an isolated abnormality "1-isolated", two abnormalities in initial association "2-initial", two abnormalities in posterior association "2-posterior", $\geq 3$ abnormalities in initial association "3-initial", $\geq 3$ abnormalities in posterior association "3-posterior"); and iv) the abnormalities occurrence's order(Spiculated-mas first, Microcalcification first, Obscured-mass first, Asymmetric-density first, Architectural-distortion first, $\geq 2$ abnormalities appeared first); v) use of hormone replacement therapy (Yes, No, Uncertain); vi) breast density (Types I to IV).

\section{Statistical analysis}

Student's t test was used to compare the age-groups (censored follow-up vs. others).

All cumulative incidences (mammographic abnormality or B-cancer) were estimated by the actuarial life-table method. Their $95 \%$ confidence-intervals were estimated by the Greenwood method.

In incidence analysis (each mammographic abnormality), the women contributed to the calculation of person-times starting from the date of first mammogram until the date of abnormality finding in the examined breast or until the end-date. Similarly, in the B-cancer incidence analysis, women contributed to the calculation of person-times starting from the date of first mammogram until the date of cancer occurrence in the examined breast or, in the absence of cancer, until the end-date. The cumulative incidences were described and compared between groups using the log-rank test or the $\mathrm{Cl}$ comparison.

The B-cancer risk analysis according to the age at finding of each mammographic abnormality was carried out by estimating the adjusted relative risk ( $\mathrm{RRa}$ ) using a multivariate Cox model. Only women who had at least one of the five mammographic abnormalities, were included in this analysis. The cox-model included all covariates regardless of their $p$-values in univariate analysis. Because of their multiple collinearities, the five variables relative to the presence of an abnormality in the contralateral breast were introduced into the final model in three modalities (Absent, Present ("Anterior"+"Same_date"+"Posterior") and NA). 
The parameters of the model were estimated by the maximum likelihood method. All analyses were performed using STATA software version 13 (College Station, Texas, USA). The threshold of statistical significance was $5 \%$.

\section{Results}

The study included 261,083 women whose mean age ( \pm standard deviation) at first mammogram was $57.3 \pm 6.6$ years. Of these, $40,208(15,4 \%)$ had a censored follow-up before 74 years of age because of death (132), loss to follow-up $(38,194)$, relocation (411), or refusal to participate in the $\operatorname{BCSP}(1,471)$. At baseline, women censured for refusal of participation or death were significantly older than the others $(59.2 \pm 5,8$ years vs. $57.3 \pm 6.6$ years, $p<0.0001$ and $58.7 \pm 5.7$ years vs. $57.3 \pm 6.6$ years, $p<0.0001$, respectively) but women censored for relocation or loss to follow-up were significantly younger ( $55.8 \pm 5.0$ years vs. $57.3 \pm 6.6$ years, $p<0.0001$ and $56.3 \pm 5.0$ years vs. $57.3 \pm 6.6$ years, $p<0.0001$, respectively).

\section{Incidence of mammographic abnormalities}

On average, women had 4.1 \pm 1.7 mammograms; some had 8 (656 women) or 9(2 women) mammograms. The mean delay between two consecutive mammograms was $2.5 \pm 0.9$ years. At least one of the five mammographic abnormalities was observed in 122,343 women (46.9\%) at an average age of $60.0 \pm 6.8$ years. The average duration of follow-up was 4.9 years. The overall incidence of mammographic abnormality (any abnormality, any breast) was estimated at 95.4/1000 person-years (p-y) [IC: $94.9 ; 95.9]$. Regarding breast laterality, 87,592 women had at least one abnormality in the left breast vs. 85,158 women with at least one abnormality in the right breast (estimated incidence 59.2/1000 p-y [58.8; 59.5] vs. 56.9/1000 p-y [56.6; 57.3]).

The mean age at first finding of a mammographic abnormality was 60.3 \pm 6.7 years (range: $51-74$ years). The mean follow-up (time-at-risk) before this finding ranged from 6.1 years (obscured-mass) to 7.2 years (spiculated-mass) with no difference between right and left breasts (Table-1). Regardless of laterality, the incidence of microcalcifications increased whereas the incidence of obscured-mass decreased with breast density.

In the left-breast, the first abnormality found at a mean age of $60.3 \pm 6.8$ years, was microcalcification ( $8.6 \%$ of cases) or spiculated-mass $(7.7 \%)$, or obscured-mass $(60.5 \%)$, or asymmetric-density $(4.9 \%)$, or architectural-distortion $(7.1 \%)$, or a combination of at least two abnormalities (11.2\%). In the right-breast, the mean age at the finding of the first abnormality was $60.2 \pm 6.7$ years and the proportions of the abnormalities cited above were respectively: $9.2 \%, 7.7 \%, 60.1 \%, 5.1 \%, 8.1 \%$, and $9.8 \%$. In the left-breast, this first abnormality was detected in $40.8 \%$ of cases at the $1^{\text {st }}$ mammogram (M1), $24.3 \%$ at $M 2,14.8 \%$ at $M 3$, and $20.1 \%$ at M4 or later. In the right breast, these percentages were respectively: $40.5,24.4,15.0$, and 20.2 at M4 or later.

\section{Incidence of breast cancer}

In the 261,083 participants followed for 7.4 years on average, at least one B-cancer was found in 6,326 women (3,137 left breast, 2,802 right breast, 257 bilateral, 130 unspecified location), which represents an incidence of 3.3/1000 p-y [3.0; 3,1]. The cancers were ADK-I (63.8\%), TIS (10.5\%), "rare form"(2.7\%) or unspecified (23.0\%). These cancers were cancer-R1 (84.5\%), cancer-R2(4.5\%) or interval-cancers (11.0\%). $88.4 \%$ of the 130 cancers whose laterality (left/right) was not specified, were interval-cancers.

The mean age at diagnosis of B-cancer was $63.8 \pm 6.3$ years, and $20.5 \%$ of cancers were diagnosed in women with none of the five mammographic abnormalities. Among 2,414 cases of the 5,028 cases associated with at least one of the five mammographic abnormalities, the abnormality (single in $64.4 \%$ of cases) was seen on the mammography that initiated the Bcancer diagnostic procedure.

B-cancer cumulative-incidence was significantly lower in women with no mammographic abnormality than in those with at least one abnormality (Left-Breast: 0.6[0.6; 0.7] vs. 3.6[3.5; 3.7], Right-Breast: 0.6[0.5; 0.6] vs. 3.3[3.2; 3.4]). The incidence of B-cancer was 5 times higher in women with than without spiculated-mass (Left-Breast: 7.7[7.2; 8.2] vs. 1.4[1.3; 1.5]; Right-Breast: 6.9[6.4; 7.4] vs. 1.3[1.2; 1.3]) (Table-2). 
Although the confidence-intervals are overlapped a few times, the Log-rank test concludes that there is a significant difference regardless of the explanatory variable (Table-3). The incidence of B-cancer increased significantly $(p<0.0001)$ with the finding age of spiculated-mass (Left-Breast: 50-54 years: 4.2[3.3; 5.2]; $\geq 70$ years: 13.0[11.2; 15.2]) or with the finding age of microcalcification (Left-Breast: $50-54$ years: $5.8[5.1 ; 6.7] ; \geq 70$ years: $12.2[10.4 ; 14.4]$ ). Whatever the abnormality, the incidence of B-cancer was higher when the abnormality was present only in the examined breast (absent in the contralateral breast) (Table3).

The incidence was constant between the second and eighth mammograms. Women with spiculated mass diagnosed before any other abnormality had a higher incidence between M2 and M7 than other women (Figure 1). Similarly, women with an association (initial or posterior) of at least three of the five abnormalities had higher incidence rates between M2 and M7 (Figure-2).

Compared to 50-54 years, the B-cancer risk was 1.7 times higher when the architectural distortion finding age was 65-69years $\left(R_{\mathrm{a}}\right.$ : 1.4[1.0; 2.0], $\left.\mathrm{p}=0.03\right)$ (Table-4). According to the spiculated-mass finding age, the B-cancer risk increased by at least $40 \%$

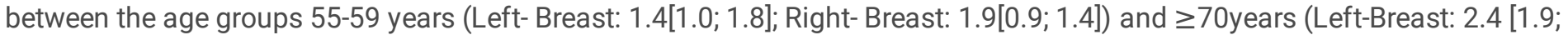
3.3]; Right-Breast: 2.0 [1.5; 2.7]).

\section{Discussion}

This study, which involved, on average, a series of four mammograms per woman, showed a high incidence of B-cancer based on five radiological abnormalities. The B-cancer risk increased with the finding age of spiculated-mass and microcalcification. Whatever the abnormality, the B-cancer risk was higher when the abnormality was present only in the examined breast. The study made it possible to estimate the mean delays: i) D1 between first mammogram and the finding of radiological abnormality; ii) D2 between first mammogram and the B-cancer diagnosis; iii) D3 between the finding of radiological abnormality and B-cancer diagnosis. When the mammographic finding was a spiculated-mass, an asymmetric-density, or an architectural-distortion, D3 was shorter than the usual two-year delay between two mammograms in the BCSP. This converges with the recommendation to perform other mammograms between two campaigns in case of mammographic finding classified ACR3.

Although the observed delay between two consecutive mammograms was greater than two years (the delay recommended by the BCSP [2-4]), this study showed that having a normal mammogram does not reduce the B-cancer risk during the next mammogram. Actually, this stability between the second and the seventh mammograms is consistent with trends in the stability of incidence already described in France [28] and Spain [29].

The link between aging and B-cancer and the link between B-cancer and each mammographic abnormality has been already described [6] [10] [11, 13] [9] [30]. In view of these previous data, it should be recognized that the increased risk of B-cancer with the spiculated-mass finding age (observed here) is comparable to a synergy between two risk factors (age and spiculatedmass). In addition, the lower risk associated with radiological abnormalities in both breasts on the same date in comparison with an isolated abnormality in one breast is poorly documented, especially in a screening context. This should alert radiologists to the relevance of certain diagnostic procedures in the presence of a bilateral radiological finding, especially since this study showed that there is more localization of cancer in the left breast compared to the right breast. This lower risk would explain the low proportion of bilateral cancers seen in this study. Moreover, it has been shown that there is no apparent increase in the risk of developing a contralateral B-cancer according to the histology of primary cancer [31,32]. A quantitative analysis of homolateral views of mammograms would provide useful information regarding B-cancer risk over the short term [16-18]. In France, since post-diagnostic follow-up is usually carried out outside the BCSP, this study cannot predict on the evolution of the radiological abnormality in the contralateral breast after B-cancer diagnosis.

The absence of radiological abnormality was related to the histopathological characteristics of the tumor modulated by patient's specific factors. Thus, a small-size tumor, the absence of microcalcifications (often linked with tumor necrosis), or a 
minimal or absent stroma reaction do not facilitate lesion detection, especially in a radiologically dense breast [14]. In this study, any risk of B-cancer was not found related to breast density.

By increasing breast density, hormone replacement therapy (HRT) is associated with an increased risk of disagreement between mammogram readers, especially regarding breast for mass [33]. HRT is also associated with B-cancer [29]. In France, the risk of B-cancer differs according to the type of estrogen-progesterone combination [34]. In this study, women with HRT (vs. others) had a lower incidence of microcalcifications, a higher incidence of asymmetry, a higher incidence of B-cancer but same order risk of B-cancer.

In France, B-cancer's detection rate was stable since 2004 [35]; it was estimated at 7/1000 p-y in women participating in a biennial BCSP campaign. In the current controversy over the usefulness of BCSP [36-38], the high incidence showed in this study, highlights the benefit the BCSP and the need to strengthen the follow-up after the finding of a radiological abnormality. In terms of B-cancer morbidity estimation, the present results agree with other incidence studies [12, 29, 39].

\section{Limitations}

The incidence rates found here may be underestimated because of incomplete data due to censoring before age of 74 for loss to follow-up or relocation while the results of last mammograms were classified ACR 3, 4 or 5.

Based on mammographic reading reports, this study cannot establish, with certainty, the link between a radiological abnormality seen during a mammogram and a similar abnormality seen during a subsequent mammogram.

The lack of interconnection between departmental databases does not make it possible to know the antecedents of women who have relocated one or more times between the age of 50-74 years. Women excluded because having only one participation in BCSP probably have a history of BCSP campaigns participation in other departments.

\section{Conclusion}

The study highlights a stable incidence of B-cancer between successive mammograms, an increased risk of B-cancer with the finding age of spiculated-mass and microcalcification. The reduced delay between the mammographic findings date and the Bcancer diagnosis date would justify a specific follow-up protocol after the finding of certain mammographic findings, in particular spiculated-mass. The low risk related to the presence of the same mammographic abnormality in both breasts compared to the presence of the isolated mammographic abnormality in one of the breasts. In this period when the quality of the program remains compromised because of overdiagnostics and other diagnostic explorations deemed unnecessary by BCSP critics, these results should alert radiologists to the relevance of certain diagnostic procedures in the management of a bilateral mammographic abnormality.

\section{Declarations}

\section{Funding}

All authors declare no financial or other relationships or activities that could appear to have influenced the submitted study.

\section{Acknowledgments}

The authors are grateful to their colleagues from the BCSP management structures. The authors are grateful to Jean Iwaz (CHU de Lyon) and Claude Vernier(OECD Paris) for the thorough editing of the manuscript.

\section{Conflict of interest}

The authors have declared no conflicts of interest.

\section{Availability of data and material}


To have access to the study data, the request must be made in accordance with the French regulations in force at the time of the request.

\section{Code availability}

To access the data analysis code, request must be made to the corresponding author.

\section{Authors' contributions}

The study was conceived and designed by $\mathrm{AK}$ and $\mathrm{CB}$. The data was acquired and collated by $\mathrm{CB}, \mathrm{RR}, \mathrm{SC}$ and analyzed by AK and CB. The study was drafted and revised critically by all authors (AK, CB, RR, SC, CRM and NS) and NS was the study's guarantor. All authors gave final approval of the version to be published and have contributed to the study. No ethical approval required.

\section{Ethics approval}

The data were anonymized before analysis. The BCSPs' databases are agreed by the French "Commission Nationale de I'Informatique et des Libertés (CNIL) [40]. At the time of the study, in accordance with the French current legislation, a study that did not change the usual management of patients did not require the opinion of an ethics committee.

\section{Consent to participate}

Not applicable

\section{Consent for publication}

Not applicable

\section{References}

1. Bray F, Ferlay J, Soerjomataram I, Siegel RL, Torre LA, Jemal A. Global statistics 2018: GLOBOCAN estimates of incidence and mortality worldwide for 36 cancers in 185 countries. CA Cancer J Clin 2018.

2. Seradour B, Ancelle-Park R. [Breast cancer screening: are results of French and international programmes comparable?]. J Radiol 2006;87:1009-14.

3. JORF. Arrêté du 29 septembre 2006 relatif aux programmes de dépistage des cancers. Journal Officiel de la République Française (JORF) n²95 du 21 décembre 2006 page 19240 texte n 49 Paris, France: Journal Officiel de la République Française (JORF); 2006.

4. Schoch C. [Mass breast cancer screening program: a public health priority in France]. Bull Cancer 2002;89:1079-80.

5. [Recommendations for radiologists involved with the breast cancer screening program]. J Radiol 2003;84:1921-32.

6. Berment $\mathrm{H}$, Becette V, Mohallem M, Ferreira F, Cherel P. Masses in mammography: what are the underlying anatomopathological lesions? Diagn Interv Imaging 2014;95:124-33.

7. Eriksson M, Czene K, Pawitan Y, Leifland K, Darabi H, Hall P. A clinical model for identifying the short-term risk of breast cancer. Breast Cancer Res 2017;19:29.

8. Rominger MB, Sax EV, Figiel JH, Timmesfeld N. Occurrence and positive predictive value of additional nonmass findings for risk stratification of breast microcalcifications in mammography. Can Assoc Radiol J 2013;64:333-8.

9. Boyer B, Russ E. Anatomical-radiological correlations: architectural distortions. Diagn Interv Imaging 2014;95:134-40.

10. Henrot $P$, Leroux A, Barlier C, Genin P. Breast microcalcifications: the lesions in anatomical pathology. Diagn Interv Imaging 2014;95:141-52.

11. Farshid G, Sullivan T, Downey P, Gill PG, Pieterse S. Independent predictors of breast malignancy in screen-detected microcalcifications: biopsy results in 2545 cases. Br J Cancer 2011;105:1669-75. 
12. Nederend J, Duijm LE, Voogd AC, Groenewoud JH, Jansen FH, Louwman MW. Trends in incidence and detection of advanced breast cancer at biennial screening mammography in The Netherlands: a population based study. Breast Cancer Res 2012;14:R10.

13. Barreau B, de Mascarel I, Feuga C, et al. Mammography of ductal carcinoma in situ of the breast: review of 909 cases with radiographic-pathologic correlations. Eur J Radiol 2005;54:55-61.

14. Roger P, Delfour C, Ragu N, Serre I, Baldet P, Taourel P. [Carcinoma with false negative mammogram: when and how?]. J Radiol 2004;85:2063-7.

15. Broeders MJ, Onland-Moret NC, Rijken HJ, Hendriks JH, Verbeek AL, Holland R. Use of previous screening mammograms to identify features indicating cases that would have a possible gain in prognosis following earlier detection. Eur $\mathrm{J}$ Cancer 2003;39:1770-5.

16. Sun W, Tseng TB, Qian W, et al. A new near-term breast cancer risk prediction scheme based on the quantitative analysis of ipsilateral view mammograms. Comput Methods Programs Biomed 2018;155:29-38.

17. Tan M, Pu J, Cheng S, Liu H, Zheng B. Assessment of a Four-View Mammographic Image Feature Based Fusion Model to Predict Near-Term Breast Cancer Risk. Ann Biomed Eng 2015;43:2416-28.

18. Li Y, Fan M, Cheng H, Zhang P, Zheng B, Li L. Assessment of global and local region-based bilateral mammographic feature asymmetry to predict short-term breast cancer risk. Phys Med Biol 2018;63:025004.

19. Bennani-Baiti B, Baltzer PAT. [Artificial intelligence in the diagnosis of breast cancer : Yesterday, today and tomorrow]. Radiologe 2019.

20. Watanabe AT, Lim V, Vu HX, et al. Improved Cancer Detection Using Artificial Intelligence: a Retrospective Evaluation of Missed Cancers on Mammography. J Digit Imaging 2019;32:625-37.

21. Geras KJ, Mann RM, Moy L. Artificial Intelligence for Mammography and Digital Breast Tomosynthesis: Current Concepts and Future Perspectives. Radiology 2019;293:246-59.

22. Houssami N, Kirkpatrick-Jones G, Noguchi N, Lee Cl. Artificial Intelligence (Al) for the early detection of breast cancer: a scoping review to assess Al's potential in breast screening practice. Expert Rev Med Devices 2019;16:351-62.

23. Rodriguez-Ruiz A, Lang K, Gubern-Merida A, et al. Can we reduce the workload of mammographic screening by automatic identification of normal exams with artificial intelligence? A feasibility study. Eur Radiol 2019;29:4825-32.

24. Thomassin-Naggara I, Balleyguier C, Ceugnart L, et al. Artificial intelligence and breast screening: French Radiology Community position paper. Diagn Interv Imaging 2019;100:553-66.

25. Cai H, Huang Q, Rong W, et al. Breast Microcalcification Diagnosis Using Deep Convolutional Neural Network from Digital Mammograms. Comput Math Methods Med 2019;2019:2717454.

26. Carter SM, Rogers W, Win KT, Frazer H, Richards B, Houssami N. The ethical, legal and social implications of using artificial intelligence systems in breast cancer care. Breast 2019;49:25-32.

27. WHO. International Classification of Diseases. Geneve: World Health Organization; 1990.

28. Molinie F, Billon-Delacour S, Allioux C, Blais S, Bercelli P, Lombrail P. [Incidence and prognostic factors of breast cancer diagnosed within and outside of the organised screening program in the department of Loire-Atlantique (1991-2002)]. Rev Epidemiol Sante Publique 2008;56:41-9.

29. Roman M, Rue M, Sala M, et al. Trends in detection of invasive cancer and ductal carcinoma in situ at biennial screening mammography in Spain: a retrospective cohort study. PLoS One 2013;8:e83121.

30. Kopans DB, Swann CA, White G, et al. Asymmetric breast tissue. Radiology 1989;171:639-43.

31. Langlands F, White J, Kearins 0 , et al. Contralateral breast cancer: incidence according to ductal or lobular phenotype of the primary. Clin Radiol 2016;71:159-63.

32. de Glas NA, Engels CC, Bastiaannet E, et al. Contralateral breast cancer risk in relation to tumor morphology and age-in which patients is preoperative MRI justified? Breast Cancer Res Treat 2015;150:191-8.

33. Meye NE, Schaffer P, Hedelin G, Guldenfels C, Gairard B. [Impact of menopause hormone replacement therapy on screening mammography reading]. J Radiol 2001;82:653-9. 
34. Cordina-Duverger E, Truong T, Anger A, et al. Risk of breast cancer by type of menopausal hormone therapy: a case-control study among post-menopausal women in France. PLoS One 2013;8:e78016.

35. Quintin C, Rogel A. Évaluation du programme de dépistage organisé du cancer du sein : résultats et évolution des indicateurs de performance depuis 2004 en France métropolitaine. . Saint-Maurice, France: Santé publique France; 2019.

36. Launoy G, Duchange N, Darquy S, Moutel G. [Participation to organized screening programs: Individual and collective stakes]. Bull Cancer 2018.

37. Pivot X, Viguier J, Touboul C, et al. Breast cancer screening controversy: too much or not enough? Eur J Cancer Prev 2015;24 Suppl:S73-6.

38. Perrenoud C, Stiefel F, Bourquin C. From facts to arguments: A study of the 2014 Swiss controversy over systematic mammography screening. Patient Educ Couns 2018;101:1110-5.

39. Natal C, Caicoya M, Prieto M, Tardon A. [Breast cancer incidence related with a population-based screening program]. Med Clin (Barc) 2015;144:156-60.

40. JORF. Délibération n²017-215 du 13 juillet 2017 portant adoption d'une norme destinée à simplifier l'obligation de déclaration des traitements de données à caractère personnel ayant pour finalité le dépistage organisé du cancer du sein, du cancer colorectal et du cancer du col de l'utérus mis en œuvre par les structures de gestion conventionnées, et abrogeant la délibération $n^{\circ}$ 2015-175 du 11 juin 2015 (décision d'autorisation unique n AU-043) (NS-059) Paris, France: Journal Officiel de la République Française (JORF); 2017.

\section{Tables}

Table 1: Cumulative incidence of radiographic findings in mammography according to the characteristics of women at baseline. 


\begin{tabular}{|c|c|c|c|c|c|c|c|c|c|c|}
\hline \multirow[t]{2}{*}{$\begin{array}{l}\text { characteristics at } \\
\text { baseline }\end{array}$} & \multicolumn{2}{|c|}{ Microcalcification } & \multicolumn{2}{|c|}{ Spiculated mass } & \multicolumn{2}{|c|}{ Obscured mass } & \multicolumn{2}{|c|}{$\begin{array}{l}\text { Asymmetric } \\
\text { density }\end{array}$} & \multicolumn{2}{|c|}{$\begin{array}{l}\text { Architectural } \\
\text { distortion }\end{array}$} \\
\hline & Case $\left(T^{\star}\right)$ & $\begin{array}{l}\text { C-In } \\
{[\mathrm{Cl}} \\
95 \%]\end{array}$ & Case $\left(T^{\star}\right)$ & $\begin{array}{l}\text { C-In } \\
{[\mathrm{Cl}} \\
95 \%]\end{array}$ & Case $\left(T^{\star}\right)$ & $\begin{array}{l}\text { C-In } \\
{[\mathrm{Cl}} \\
95 \%]\end{array}$ & Case $\left(\mathrm{T}^{\star}\right)$ & $\begin{array}{l}\text { C-In } \\
{[\mathrm{Cl}} \\
95 \%]\end{array}$ & Case $\left(T^{\star}\right)$ & $\begin{array}{l}\text { C-In } \\
{[\mathrm{Cl}} \\
95 \%]\end{array}$ \\
\hline \multicolumn{11}{|l|}{ Left breast } \\
\hline $\begin{array}{l}\text { Overall } \\
(n=260,825)+\end{array}$ & $\begin{array}{l}15,257 \\
(7.1)\end{array}$ & $\begin{array}{l}8.2 \\
{[8.1 ;} \\
8.3]\end{array}$ & $\begin{array}{l}12,016 \\
(7.2)\end{array}$ & $\begin{array}{l}6.4 \\
{[6.3 ;} \\
6.5]\end{array}$ & $\begin{array}{l}65,505 \\
(6.1)\end{array}$ & $\begin{array}{l}41.1 \\
{[40.8 ;} \\
41.4]\end{array}$ & $\begin{array}{l}6,365 \\
(7.3)\end{array}$ & $\begin{array}{l}3.3 \\
{[3.2 ;} \\
3.4]\end{array}$ & $\begin{array}{l}9,681 \\
(7.2)\end{array}$ & $\begin{array}{l}5.2 \\
{[5.1 ;} \\
5.3]\end{array}$ \\
\hline \multicolumn{11}{|l|}{$\begin{array}{l}\text { Age (year) } 7^{\text {st }} \\
\text { mammogram }\end{array}$} \\
\hline $\begin{array}{l}50-54 \\
(n=125,261)\end{array}$ & $\begin{array}{l}7,037 \\
(7.0)\end{array}$ & $\begin{array}{l}8.1 \\
{[7.9} \\
8.3]\end{array}$ & $\begin{array}{l}5,659 \\
(7.1)\end{array}$ & $\begin{array}{l}6.4 \\
{[6.2 ;} \\
6.6]\end{array}$ & $\begin{array}{l}29,424 \\
(6.1)\end{array}$ & $\begin{array}{l}38.8 \\
{[38.3} \\
\vdots \\
39.2]\end{array}$ & $\begin{array}{l}3,423 \\
(7.2)\end{array}$ & $\begin{array}{l}3.8 \\
{[3.7} \\
4.0]\end{array}$ & $\begin{array}{l}4,322 \\
(7.0)\end{array}$ & $\begin{array}{l}4.9 \\
{[4.8 ;} \\
5.1]\end{array}$ \\
\hline $55-59(n=51,186)$ & $\begin{array}{l}3,482 \\
(8.6)\end{array}$ & $\begin{array}{l}7.8 \\
{[7.5} \\
8.0]\end{array}$ & $\begin{array}{l}2,882 \\
(8.9)\end{array}$ & $\begin{array}{l}6.3 \\
{[6.1 ;} \\
6.6]\end{array}$ & $\begin{array}{l}14,914 \\
(7.3)\end{array}$ & $\begin{array}{l}39.7 \\
{[39.1} \\
\vdots \\
40.3]\end{array}$ & $\begin{array}{l}1,367 \\
(9.1)\end{array}$ & $\begin{array}{l}2.9 \\
{[2.8 ;} \\
3.1]\end{array}$ & $\begin{array}{l}2,286 \\
(8.9)\end{array}$ & $\begin{array}{l}5.0 \\
{[4.8 ;} \\
5.3]\end{array}$ \\
\hline $60-64(n=40,727)$ & $\begin{array}{l}2,645 \\
(8.2)\end{array}$ & $\begin{array}{l}8.0 \\
{[7.7} \\
8.3]\end{array}$ & $\begin{array}{l}2,129 \\
(8.3)\end{array}$ & $\begin{array}{l}6.3 \\
{[6.1 ;} \\
6.6]\end{array}$ & $\begin{array}{l}11,650 \\
(6.8)\end{array}$ & $\begin{array}{l}41.9 \\
{[41.1} \\
\vdots \\
42.7]\end{array}$ & $\begin{array}{l}1,032 \\
(8.4)\end{array}$ & $\begin{array}{l}3.0 \\
{[2.8 ;} \\
3.2]\end{array}$ & $\begin{array}{l}1,674 \\
(8.2)\end{array}$ & $\begin{array}{l}5.0 \\
{[4.7 ;} \\
5.2]\end{array}$ \\
\hline $65-69(n=29,311)$ & $\begin{array}{l}1,556 \\
(5.6)\end{array}$ & $\begin{array}{l}9.5 \\
{[9.0} \\
9.9]\end{array}$ & $\begin{array}{l}992 \\
(5.7)\end{array}$ & $\begin{array}{l}5.9 \\
{[5.8 ;} \\
6.3]\end{array}$ & $6,858(4.9)$ & $\begin{array}{l}47.8 \\
{[46.7} \\
\vdots \\
49.0]\end{array}$ & $\begin{array}{l}450 \\
(5.8)\end{array}$ & $\begin{array}{l}2.7 \\
{[2.4 ;} \\
2.9]\end{array}$ & $\begin{array}{l}1,058 \\
(5.7)\end{array}$ & $\begin{array}{l}6.4 \\
{[6.0 ;} \\
6.8]\end{array}$ \\
\hline$\geq 70(n=14,340)$ & $\begin{array}{l}537 \\
(2.9)\end{array}$ & $\begin{array}{l}13.0 \\
{[12.0} \\
\vdots \\
14.2]\end{array}$ & $\begin{array}{l}354 \\
(2.9)\end{array}$ & $\begin{array}{l}8.5 \\
{[7.7} \\
9.4]\end{array}$ & $2,659(2.6)$ & $\begin{array}{l}71.4 \\
{[68.8} \\
\vdots \\
74.2]\end{array}$ & $93(2.9)$ & $\begin{array}{l}2.2 \\
{[1.8 ;} \\
2.7]\end{array}$ & $\begin{array}{l}341 \\
(2.9)\end{array}$ & $\begin{array}{l}8.2 \\
{[7.4 ;} \\
9.1]\end{array}$ \\
\hline $\begin{array}{l}\text { Breast Density } \\
1^{\text {st }} \\
\text { mammogram }\end{array}$ & & & & & & & & & & \\
\hline Type I $(n=35,040)$ & $\begin{array}{l}888 \\
(7.2)\end{array}$ & $\begin{array}{l}3.5 \\
{[3.3 ;} \\
3.7]\end{array}$ & $\begin{array}{l}1,147 \\
(7.2)\end{array}$ & $\begin{array}{l}4.5 \\
{[4.3 ;} \\
4.8]\end{array}$ & $8,764(6.1)$ & $\begin{array}{l}41.1 \\
{[40.3} \\
\vdots \\
42.0]\end{array}$ & $\begin{array}{l}582 \\
(7.3)\end{array}$ & $\begin{array}{l}2.3 \\
{[2.1 ;} \\
2.5]\end{array}$ & $\begin{array}{l}942 \\
(7.2)\end{array}$ & $\begin{array}{l}3.7 \\
{[3.5 ;} \\
4.0]\end{array}$ \\
\hline $\begin{array}{l}\text { Type II } \\
(\mathrm{n}=161,222)\end{array}$ & $\begin{array}{l}8,479 \\
(7.1)\end{array}$ & $\begin{array}{l}7.4 \\
{[7.3 ;} \\
7.6]\end{array}$ & $\begin{array}{l}7,412 \\
(7.1)\end{array}$ & $\begin{array}{l}6.4 \\
{[6.3 ;} \\
6.6]\end{array}$ & $\begin{array}{l}41,122 \\
(6.0)\end{array}$ & $\begin{array}{l}42.5 \\
{[42.1} \\
\vdots \\
42.9]\end{array}$ & $\begin{array}{l}4,057 \\
(7.2)\end{array}$ & $\begin{array}{l}3.5 \\
{[3.4 ;} \\
3.6]\end{array}$ & $\begin{array}{l}6,096 \\
(7.1)\end{array}$ & $\begin{array}{l}5.3 \\
{[5.2 ;} \\
5.5]\end{array}$ \\
\hline $\begin{array}{l}\text { Type III } \\
(n=58,524)\end{array}$ & $\begin{array}{l}5,192 \\
(7.2)\end{array}$ & $\begin{array}{l}12.3 \\
{[12.0} \\
\vdots \\
12.7]\end{array}$ & $\begin{array}{l}3,156 \\
(7.5)\end{array}$ & $\begin{array}{l}7.2 \\
{[7.0 ;} \\
7.5]\end{array}$ & $\begin{array}{l}14,377 \\
(6.4)\end{array}$ & $\begin{array}{l}38.7 \\
{[38.0} \\
\vdots \\
39.3]\end{array}$ & $\begin{array}{l}1,613 \\
(7.6)\end{array}$ & $\begin{array}{l}3.6 \\
{[3.5 ;} \\
3.8]\end{array}$ & $\begin{array}{l}2,463 \\
(7.4)\end{array}$ & $\begin{array}{l}5.7 \\
{[5.4 ;} \\
5.9]\end{array}$ \\
\hline $\begin{array}{l}\text { Type IV } \\
(n=6,039)\end{array}$ & $\begin{array}{l}698 \\
(7.2)\end{array}$ & $\begin{array}{l}16.1 \\
{[14.9} \\
\vdots \\
17.3]\end{array}$ & $\begin{array}{l}301 \\
(7.7)\end{array}$ & $\begin{array}{l}6.5 \\
{[5.8 ;} \\
7.3]\end{array}$ & $1,242(6.8)$ & $\begin{array}{l}30.3 \\
{[28.6} \\
\vdots \\
32.0]\end{array}$ & $\begin{array}{l}113 \\
(7.8)\end{array}$ & $\begin{array}{l}2.4 \\
{[2.0 ;} \\
2.9]\end{array}$ & $\begin{array}{l}180 \\
(7.7)\end{array}$ & $\begin{array}{l}3.9 \\
{[3.3 ;} \\
4.5]\end{array}$ \\
\hline $\begin{array}{l}\text { HRT } 1^{\text {st }} \\
\text { mammogram }\end{array}$ & & & & & & & & & & \\
\hline No/U(n=227,089) & $\begin{array}{l}12,711 \\
(6.9)\end{array}$ & $\begin{array}{l}8.1 \\
{[7.9} \\
8.2]\end{array}$ & $\begin{array}{l}9,977 \\
(7.0)\end{array}$ & $\begin{array}{l}6.2 \\
{[6.1 ;} \\
6.4]\end{array}$ & $55,875(6.0)$ & $\begin{array}{l}41.2 \\
{[40.9}\end{array}$ & $\begin{array}{l}5,503 \\
(7.1)\end{array}$ & $\begin{array}{l}3.4 \\
{[3.3 ;} \\
3.5]\end{array}$ & $\begin{array}{l}8,100 \\
(7.0)\end{array}$ & $\begin{array}{l}5.1 \\
{[5.0 ;} \\
5.2]\end{array}$ \\
\hline
\end{tabular}


'41.6]

$\begin{array}{lllllllllll}\text { Yes }(\mathrm{n}=33,740) & 2,546 & 9.0 & 2,039 & 7.1 & 9,630(7.1) & 40.4 & 862 & 2.9 & 1,581 & 5.5 \\ & (8.3) & {[8.7 ;} & (8.5) & {[6.8 ;} & & {[39.6} & (8.7) & {[2.7 ;} & (8.5) & {[5.3 ;} \\ & & 9.4] & & 7.4] & & ; & & & \\ & & & & & & & & & \end{array}$

Right breast

Overall $(\mathrm{n}=$

$260,854)^{+t}$

15,040
$(7.1)$

$8.1 \quad 11,449$

[8.0; (7.2)

8.2]

6.1

$\begin{array}{ll}6.1 & 62,932 \\ {[6.0 ;} & (6.2)\end{array}$

6.2]

39.2 6,309

[38.9; (7.3)

$\begin{array}{ll}3.3 & 9,332 \\ 3.2 & (7.2)\end{array}$

[3.2; (7.2)

5.0

39.5]

3.4]

[4.9;

5.1]

Age (year) $7^{\text {st }}$

mammogram

Table 2: Breast cancer Cumulative incidence according to the presence of mammographic abnormalities. 


\begin{tabular}{|c|c|c|c|c|c|c|c|c|}
\hline \multirow{3}{*}{$\begin{array}{l}\text { Mammographic } \\
\text { abnormalities }\end{array}$} & \multicolumn{8}{|c|}{ Cumulative Incidence } \\
\hline & \multicolumn{4}{|l|}{ Left breast } & \multicolumn{4}{|l|}{ Right breast } \\
\hline & $\begin{array}{l}\mathrm{Nb} \text { of women } \\
\left(T^{\star}\right)\end{array}$ & $P-Y$ & Case & $\begin{array}{l}\mathrm{C}-\ln [\mathrm{Cl} \\
95 \%]\end{array}$ & $\begin{array}{l}\mathrm{Nb} \text { of } \\
\text { women }\left(T^{\star}\right)\end{array}$ & $P-Y$ & Case & $\begin{array}{l}\mathrm{C}- \\
\ln [\mathrm{Cl} \\
95 \%]\end{array}$ \\
\hline Overall & $\begin{array}{l}260,825(7.6) \\
+\end{array}$ & $1,953,560.6$ & 3,394 & $\begin{array}{l}1.7[1.7 \\
; 1.8]\end{array}$ & $\begin{array}{l}260,854 \\
(7.5)+\dagger\end{array}$ & $1,953,706.4$ & 3,059 & $\begin{array}{l}1.6 \\
{[1.5 ;} \\
1.6]\end{array}$ \\
\hline \multicolumn{9}{|l|}{$\begin{array}{l}\text { Mammographic } \\
\text { abnormalities }\end{array}$} \\
\hline No abnormality & $173,233(7.1)$ & $1,229,252.5$ & 785 & $\begin{array}{l}0.6[0.6 \\
; 0.7]\end{array}$ & $\begin{array}{l}175,696 \\
(7.1)\end{array}$ & $1,249,074.8$ & 731 & $\begin{array}{l}0.6 \\
{[0.5 ;} \\
0.6]\end{array}$ \\
\hline$\geq 1$ abnormality & $87,592(8.3)$ & $724,308.1$ & 2,609 & $\begin{array}{l}3.6[3.5 \\
; 3.7]\end{array}$ & $85,158(8.3)$ & $704,631.6$ & 2,328 & $\begin{array}{l}3.3 \\
{[3.2 ;} \\
3.4]\end{array}$ \\
\hline \multicolumn{9}{|l|}{ Microcalcification } \\
\hline No & $245,568(7.4)$ & $1,826,457.0$ & 2,417 & $\begin{array}{l}1.3[1.3 \\
; 1.4]\end{array}$ & $\begin{array}{l}245,814 \\
(7.4)\end{array}$ & $1,827,982.0$ & 2,185 & $\begin{array}{l}1.2 \\
{[1.1 ;} \\
1.2]\end{array}$ \\
\hline Yes & $15,257(8.3)$ & $127,103.6$ & 977 & $\begin{array}{l}7.7[7.2 \\
; 8.2]\end{array}$ & $15,040(8.4)$ & $125,724.5$ & 874 & $\begin{array}{l}7.0 \\
{[6.5 ;} \\
7.4]\end{array}$ \\
\hline \multicolumn{9}{|l|}{ Spiculated mass } \\
\hline No & $248,809(7.4)$ & $1,848,301.9$ & 2,587 & $\begin{array}{l}1.4[1.3 \\
; 1.5]\end{array}$ & $\begin{array}{l}249,405 \\
(7.4)\end{array}$ & $1,853,980.0$ & 2,370 & $\begin{array}{l}1.3 \\
{[1.2 ;} \\
1.3]\end{array}$ \\
\hline Yes & $12,016(8.9)$ & $105,258.7$ & 807 & $\begin{array}{l}7.7[7.2 \\
; 8.2]\end{array}$ & $11,449(8.7)$ & $99,726.5$ & 689 & $\begin{array}{l}6.9 \\
{[6.4 ;} \\
7.4]\end{array}$ \\
\hline \multicolumn{9}{|l|}{ Obscured mass } \\
\hline No & $195,320(7.2)$ & $1,407691.3$ & 1,959 & $\begin{array}{l}1.4[1.3 \\
; 1.5]\end{array}$ & $197,922(7.2)$ & $1,429,130.8$ & 1,794 & $\begin{array}{l}1.3 \\
{[1.2 ;} \\
1.3]\end{array}$ \\
\hline Yes & $65,505(8.3)$ & $545,869.3$ & 1,435 & $\begin{array}{l}2.6[2.5 \\
; 2.8]\end{array}$ & $62,932(8.3)$ & $524,575.7$ & 1,265 & $\begin{array}{l}2.4 \\
{[2.3 ;} \\
2.5]\end{array}$ \\
\hline \multicolumn{9}{|c|}{ Asymmetric density } \\
\hline No & $254,460(7.5)$ & $1,900756.4$ & 2,983 & $\begin{array}{l}1.6[1.5 \\
; 1.6]\end{array}$ & $\begin{array}{l}254,545 \\
(7.5)\end{array}$ & $1,901,211.3$ & 2,715 & $\begin{array}{l}1.4 \\
{[1.4 ;} \\
1.5]\end{array}$ \\
\hline Yes & 6,365 (8.3) & $52,804.2$ & 411 & $\begin{array}{l}7.8[7.1 \\
; 8.6]\end{array}$ & $6,309(8.3)$ & $52,495.1$ & 344 & $\begin{array}{l}6.6 \\
{[5.9} \\
7.3]\end{array}$ \\
\hline \multicolumn{9}{|c|}{ Architectural distortion } \\
\hline No & $251,144(7.4)$ & $1,869595.7$ & 3,034 & $\begin{array}{l}1.6[1.6 \\
; 1.7]\end{array}$ & $\begin{array}{l}251,522 \\
(7.5)\end{array}$ & $1,872,887.6$ & 2,671 & $\begin{array}{l}1.4 \\
{[1.4 ;} \\
1.5]\end{array}$ \\
\hline Yes & $9,681(8.7)$ & $83,964.9$ & 360 & $\begin{array}{l}4.3[3.9 \\
; 4.8]\end{array}$ & $9,332(8.7)$ & $80,818.9$ & 388 & $\begin{array}{l}4.8 \\
{[4.3 ;}\end{array}$ \\
\hline
\end{tabular}


$\mathrm{T}^{\star}$ Average time at risk (in year) $-{ }^{\dagger} 258$ women did not have the left breast $-{ }^{{ }^{\dagger \dagger}} 229$ women did not have the right breast $-\mathrm{C}-\mathrm{In}$ [Cl 95\%]: cumulative incidence per 1000 person-year [95\% confidence interval] - Nb: Number - P-Y: Person-year.

Table 3: Cumulative incidence by type of cancer's localization (left/right), according to the characteristics of the radiological abnormalities and the characteristics of the women. 


\begin{tabular}{|c|c|c|c|c|c|c|}
\hline \multirow[t]{2}{*}{ Characteristics } & \multicolumn{3}{|c|}{$\begin{array}{l}\text { Left-Breast cancer's Cumulative } \\
\text { Incidence }\end{array}$} & \multicolumn{3}{|c|}{$\begin{array}{l}\text { Right-Breast cancer's Cumulative } \\
\text { Incidence }\end{array}$} \\
\hline & $\begin{array}{l}\mathrm{Nb} \text { of } \\
\text { women }\end{array}$ & Case & C-In [CI 95\%] & $\begin{array}{l}\mathrm{Nb} \text { of } \\
\text { women }\end{array}$ & Case & C-In [Cl 95\%] \\
\hline Overall & $260,825^{\dagger}$ & 3,394 & $1.7[1.7 ; 1.8]$ & $260,854^{\dagger \dagger}$ & 3,059 & $1.6[1.5 ; 1.6]$ \\
\hline Finding age(year): Microcalcification & & & * & & & * \\
\hline Absent & 245,568 & 2,417 & $1.3[1.3 ; 1.4]$ & 245,814 & 2,185 & $1.2[1.1 ; 1.2]$ \\
\hline $50-54$ & 4,328 & 190 & $5.8[5.1 ; 6.7]$ & 4,241 & 157 & $4.9[4.2 ; 5.7]$ \\
\hline $55-59$ & 3,544 & 214 & $6.7[5.9 ; 7.7]$ & 3,469 & 181 & $5.8[5.0 ; 6.7]$ \\
\hline $60-64$ & 3,178 & 253 & $8.4[7.4 ; 9.5]$ & 3,175 & 214 & $7.2[6.3 ; 8.2]$ \\
\hline $65-69$ & 2,458 & 174 & $8.4[7.2 ; 9.7]$ & 2,458 & 177 & $8.5[7.3 ; 9.8]$ \\
\hline$\geq 70$ & 1,749 & 146 & $\begin{array}{l}12.2[10.4 ; \\
14.4]\end{array}$ & 1,697 & 145 & $\begin{array}{l}12.5[10.6 \\
14.7]\end{array}$ \\
\hline $\begin{array}{l}\text { Contralateral presence if a } \\
\text { Microcalcification seen }\end{array}$ & & & * & & & * \\
\hline Absent & 5,631 & 650 & $\begin{array}{l}14.3[13.2 ; \\
15.4]\end{array}$ & 5,414 & 554 & $\begin{array}{l}12.5[11.5 \\
13.6]\end{array}$ \\
\hline Anterior & 287 & 17 & $\begin{array}{l}6.2[3.9 \\
10.0]\end{array}$ & 286 & 27 & $\begin{array}{l}10.1[6.9 \\
14.7]\end{array}$ \\
\hline Same date & 9,053 & 295 & $3.9[3.5 ; 4.3]$ & 9,053 & 285 & $3.7[3.3 ; 4.2]$ \\
\hline Posterior & 286 & 15 & $5.6[3.4 ; 9.3]$ & 287 & 8 & $2.9[1.5 ; 5.9]$ \\
\hline Finding age(year): Spiculated mass & & & * & & & * \\
\hline Absent & 248,809 & 2,587 & $1.4[1.3 ; 1.5]$ & 249,405 & 2370 & $1.3[1.2 ; 1.3]$ \\
\hline $50-54$ & 2,593 & 78 & $4.2[3.3 ; 5.2]$ & 2,438 & 74 & $4.4[3.5 ; 5.5]$ \\
\hline $55-59$ & 2,813 & 151 & $6.0[5.1 ; 7.1]$ & 2,687 & 118 & $4.9[4.1 ; 5.9]$ \\
\hline $60-64$ & 2,738 & 199 & $7.3[6.3 ; 8.3]$ & 2,669 & 181 & $6.8[5.8 ; 7.8]$ \\
\hline $65-69$ & 2,278 & 215 & $\begin{array}{l}10.0[8.8 ; \\
11.4]\end{array}$ & 2,195 & 180 & $\begin{array}{l}8.7[7.5 \\
10.1]\end{array}$ \\
\hline$\geq 70$ & 1,594 & 164 & $\begin{array}{l}13.0[11.2 ; \\
15.2]\end{array}$ & 1,460 & 136 & $\begin{array}{l}11.8[10.0 \\
14.0]\end{array}$ \\
\hline $\begin{array}{l}\text { Contralateral presence if a Spiculated mass } \\
\text { seen }\end{array}$ & & & * & & & * \\
\hline Absent & 8,581 & 753 & $\begin{array}{l}10.1[9.4 ; \\
10.9]\end{array}$ & 8,014 & 642 & $\begin{array}{l}9.3[8.6 \\
10.1]\end{array}$ \\
\hline Anterior & 336 & 12 & $3.6[2.0 ; 6.3]$ & 348 & 10 & $2.8[1.5 ; 5.2]$ \\
\hline Same date & 2,751 & 36 & $1.5[1.1 ; 2.1]$ & 2,751 & 32 & $1.3[0.9 ; 1.9]$ \\
\hline Posterior & 348 & 6 & $1.7[0.8 ; 3.8]$ & 336 & 5 & $1.5[0.6 ; 3.6]$ \\
\hline Finding age(year): Obscured mass & & & * & & & * \\
\hline Absent & 195,320 & 1,959 & $1.4[1.3 ; 1.5]$ & 197,922 & 1,794 & $1.3[1.2 ; 1.3]$ \\
\hline $50-54$ & 18,256 & 291 & $2.2[1.9 ; 2.4]$ & 17,553 & 236 & $1.8[1.6 ; 2.1]$ \\
\hline
\end{tabular}




\begin{tabular}{|c|c|c|c|c|c|c|}
\hline $55-59$ & 15,534 & 345 & $2.4[2.2 ; 2.7]$ & 14,874 & 298 & $2.2[2.0 ; 2.5]$ \\
\hline $60-64$ & 14,120 & 373 & $2.7[2.5 ; 3.0]$ & 13,709 & 336 & $2.5[2.3 ; 2.8]$ \\
\hline $65-69$ & 10,552 & 274 & $3.1[2.7 ; 3.5]$ & 10,030 & 253 & $3.0[2.7 ; 3.4]$ \\
\hline$\geq 70$ & 7,043 & 152 & $3.4[2.9 ; 4.0]$ & 6,766 & 142 & $3.3[2.8 ; 3.9]$ \\
\hline $\begin{array}{l}\text { Contralateral presence if an Obscured- } \\
\text { mass seen }\end{array}$ & & & * & & & * \\
\hline Absent & 32,813 & 891 & $3.4[3.1 ; 3.6]$ & 30,240 & 760 & $3.1[2.9 ; 3.3]$ \\
\hline Anterior & 5,521 & 117 & $2.3[1.9 ; 2.7]$ & 5,750 & 140 & $2.6[2.2 ; 3.0]$ \\
\hline Same date & 21,421 & 351 & $2.0[1.8 ; 2.2]$ & 21,421 & 313 & $1.8[1.6 ; 2.0]$ \\
\hline Posterior & 5,750 & 76 & $1.4[1.1 ; 1.8]$ & 5,521 & 52 & $1.0[0.8 ; 1.3]$ \\
\hline Finding age(year): Asymmetric density & & & * & & & * \\
\hline Absent & 254,460 & 2,983 & $1.6[1.5 ; 1.6]$ & 254,545 & 2,715 & $1.4[1.4 ; 1.5]$ \\
\hline $50-54$ & 1,482 & 54 & $6.8[5.2 ; 8.9]$ & 1,409 & 40 & $5.5[4.0 ; 7.4]$ \\
\hline $55-59$ & 1,415 & 79 & $6.7[5.4 ; 8.4]$ & 1,422 & 84 & $7.1[5.8 ; 8.8]$ \\
\hline $60-64$ & 1,444 & 106 & $7.4[6.2 ; 9.0]$ & 1,486 & 85 & $5.8[4.7 ; 7.2]$ \\
\hline $65-69$ & 1,201 & 93 & $7.9[6.5 ; 9.7]$ & 1,219 & 79 & $6.6[5.3 ; 8.2]$ \\
\hline$\geq 70$ & 823 & 79 & $\begin{array}{l}11.2[9.0 ; \\
13.9]\end{array}$ & 773 & 56 & $\begin{array}{l}8.3[6.4 \\
10.8]\end{array}$ \\
\hline $\begin{array}{l}\text { Contralateral presence if an asymmetry } \\
\text { seen }\end{array}$ & & & * & & & * \\
\hline Absent & 5,262 & 405 & $\begin{array}{l}9.3[8.4 \\
10.3]\end{array}$ & 5,206 & 333 & $7.7[6.9 ; 8.6]$ \\
\hline Anterior & 162 & 2 & $1.4[0.4 ; 5.6]$ & 190 & 0 & 0 \\
\hline Same date & 751 & 4 & $0.7[0.2 ; 1.7]$ & 751 & 9 & $1.5[0.8 ; 2.8]$ \\
\hline Posterior & 190 & 0 & 0 & 162 & 2 & $1.4[0.4 ; 5.6]$ \\
\hline Finding age(year): Architectural distortion & & & * & & & * \\
\hline Absent & 251,144 & 3,034 & $1.6[1.6 ; 1.7]$ & 251,522 & 2,671 & $1.4[1.4 ; 1.5]$ \\
\hline $50-54$ & 2,646 & 60 & $2.8[2.2 ; 3.6]$ & 2,517 & 76 & $3.8[3.1 ; 4.8]$ \\
\hline $55-59$ & 2,415 & 71 & $3.1[2.5 ; 3.9]$ & 2,329 & 72 & $3.3[2.6 ; 4.1]$ \\
\hline $60-64$ & 2,090 & 98 & $4.8[3.9 ; 5.8]$ & 2,045 & 84 & $4.2[3.4 ; 5.2]$ \\
\hline $65-69$ & 1,561 & 70 & $5.2[4.1 ; 6.6]$ & 1,5 & 96 & $7.5[6.1 ; 9.2]$ \\
\hline$\geq 70$ & 969 & 61 & $\begin{array}{l}10.1[7.9 ; \\
13.0]\end{array}$ & 941 & 60 & $\begin{array}{l}10.2[7.9 \\
13.1]\end{array}$ \\
\hline Contralateral presence if a distortion seen & & & * & & & * \\
\hline Absent & 7,043 & 328 & $5.4[4.8 ; 6.0]$ & 6,694 & 358 & $6.2[5.6 ; 6.9]$ \\
\hline Anterior & 246 & 10 & $4.1[2.2 ; 7.7]$ & 258 & 5 & $2.0[0.8 ; 4.7]$ \\
\hline Same date & 2,134 & 20 & $1.1[0.7 ; 1.7]$ & 2,134 & 23 & $1.3[0.9 ; 1.9]$ \\
\hline Posterior & 258 & 2 & $0.8[0.2 ; 3.1]$ & 246 & 2 & $0.8[0.2 ; 3.3]$ \\
\hline
\end{tabular}




\begin{tabular}{|c|c|c|c|c|c|c|}
\hline Abnormalities's concomitance & & & * & & & * \\
\hline No Abnormality & 173,233 & 785 & $0.6[0.6 ; 0.7]$ & 175,696 & 731 & $0.6[0.5 ; 0.6]$ \\
\hline 1-isolated & 69,116 & 1,517 & $2.7[2.6 ; 2.8]$ & 67,823 & 1,358 & $2.5[2.3 ; 2.6]$ \\
\hline 2-initial & 6,702 & 397 & $7.4[6.7 ; 8.1]$ & 6,294 & 340 & $6.7[6.0 ; 7.4]$ \\
\hline 2-posterior & 9,222 & 444 & $5.1[4.7 ; 5.6]$ & 8,685 & 416 & $5.1[4.7 ; 5.7]$ \\
\hline 3-initial & 413 & 67 & $\begin{array}{l}20.3[16.0 ; \\
25.8]\end{array}$ & 397 & 49 & $\begin{array}{l}15.4[11.7 ; \\
20.4]\end{array}$ \\
\hline 3-posterior & 2,139 & 184 & $\begin{array}{l}8.8[7.6 \\
10.2]\end{array}$ & 1,959 & 165 & $\begin{array}{l}8.6[7.4 ; \\
10.0]\end{array}$ \\
\hline Abnormalities occurrence's order & & & * & & & * \\
\hline Spiculated-mass first & 6,725 & 348 & $6.1[5.5 ; 6.8]$ & 6,576 & 288 & $5.2[4.6 ; 5.8]$ \\
\hline Obscured-mass first & 53,019 & 856 & $2.0[1.8 ; 2.1]$ & 51,183 & 776 & $1.8[1.7 ; 2.0]$ \\
\hline Microcalcification first & 7,569 & 394 & $6.4[5.8 ; 7.1]$ & 7,815 & 350 & $5.5[4.9 ; 6.1]$ \\
\hline Architectural distortion first & 7,087 & 179 & $2.9[2.5 ; 3.4]$ & 6,916 & 208 & $3.5[3.0 ; 4.0]$ \\
\hline Asymmetric density first & 4,328 & 247 & $7.1[6.3 ; 8.1]$ & 4,305 & 208 & $6.0[5.3 ; 6.9]$ \\
\hline$\geq 2$ abnormalities first & 8,864 & 585 & $7.9[7.3 ; 8.6]$ & 8,363 & 498 & $7.2[6.6 ; 7.8]$ \\
\hline Hormone Replacement Therapy & & & * & & & * \\
\hline No/Unspecified & 227,085 & 2,785 & $1.7[1.6 ; 1.7]$ & 227,111 & 2,545 & $1.5[1.5 ; 1.6]$ \\
\hline Yes & 33,740 & 609 & $2.0[1.9 ; 2.2]$ & 33,743 & 514 & $1.7[1.6 ; 1.9]$ \\
\hline Breast density & & & * & & & * \\
\hline D-I & 35,040 & 322 & $1.2[1.1 ; 1.4]$ & 35,046 & 267 & $1.0[0.9 ; 1.2]$ \\
\hline D-II & 161,222 & 2,059 & $1.7[1.7 ; 1.8]$ & 161,248 & 1,876 & $1.6[1.5 ; 1.6]$ \\
\hline D-III & 58,524 & 926 & $2.0[1.9 ; 2.2]$ & 58,52 & 827 & $1.8[1.7 ; 2.0]$ \\
\hline D-IV & 6,039 & 87 & $1.8[1.5 ; 2.2]$ & 6,040 & 89 & $1.9[1.5 ; 2.3]$ \\
\hline
\end{tabular}

* Pr>chi2<0.0001 (Log-rank test) $-{ }^{\dagger} 258$ did not have the left breast $-{ }^{\dagger \dagger} 229$ did not have the right breast $-\mathrm{C}-\mathrm{In}[\mathrm{Cl} 95 \%]$ : cumulative incidence/1000P-Y [95\% confidence interval] - Nb: Number.

Figures 


\section{Abnormalities occurrence's order}
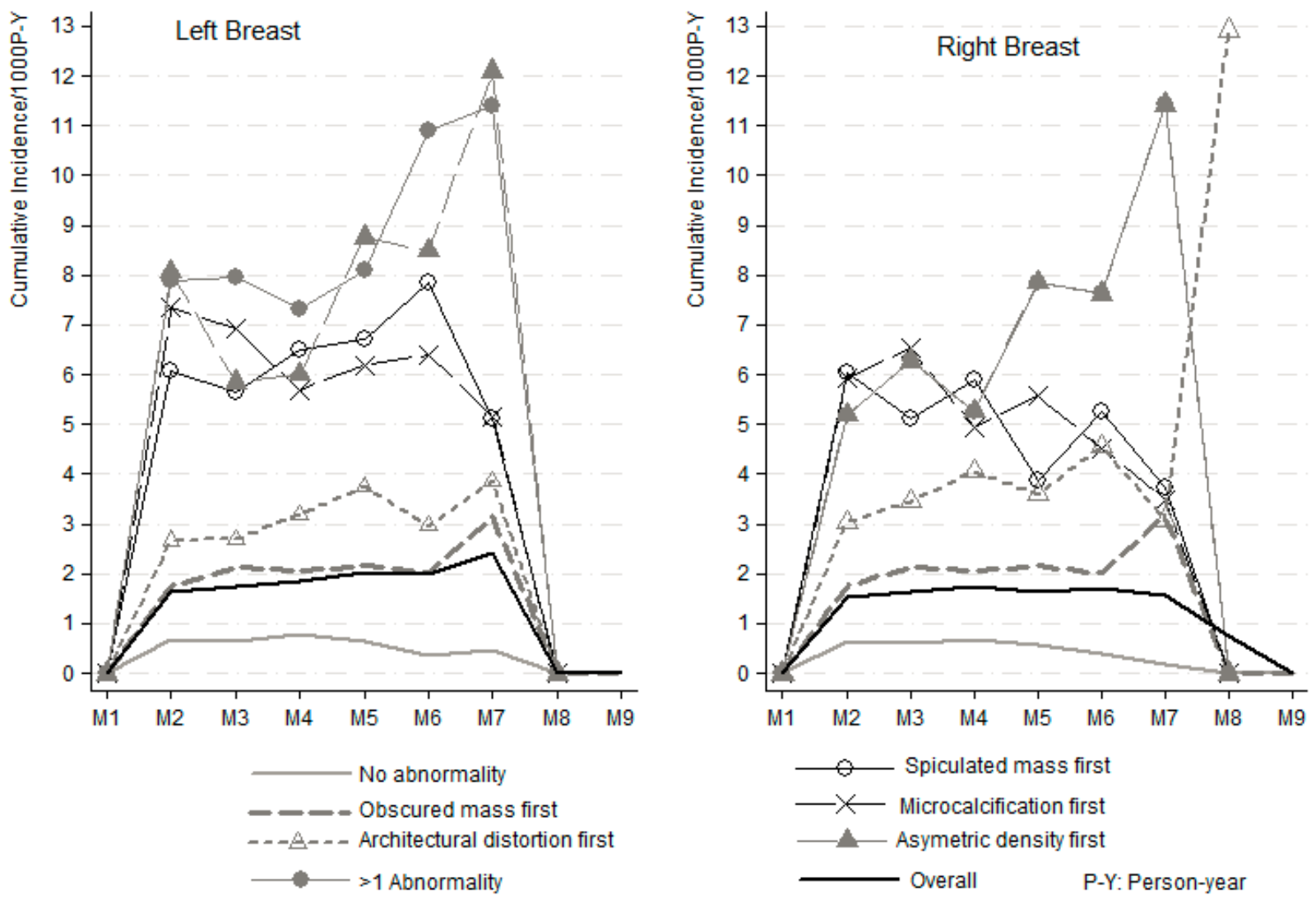

Figure 1

Evolution of the cumulative incidence according to the order of occurrence of the radiological abnormalities in the left and right breast and according by the screening mammogram (M) rank. No abnormality (no abnormality in the breast concerned); $>1$ abnormality (Several abnormalities first occurred on the same date); Overall (Sample Cumulative Incidence). 


\section{Abnormalities's concomitance}
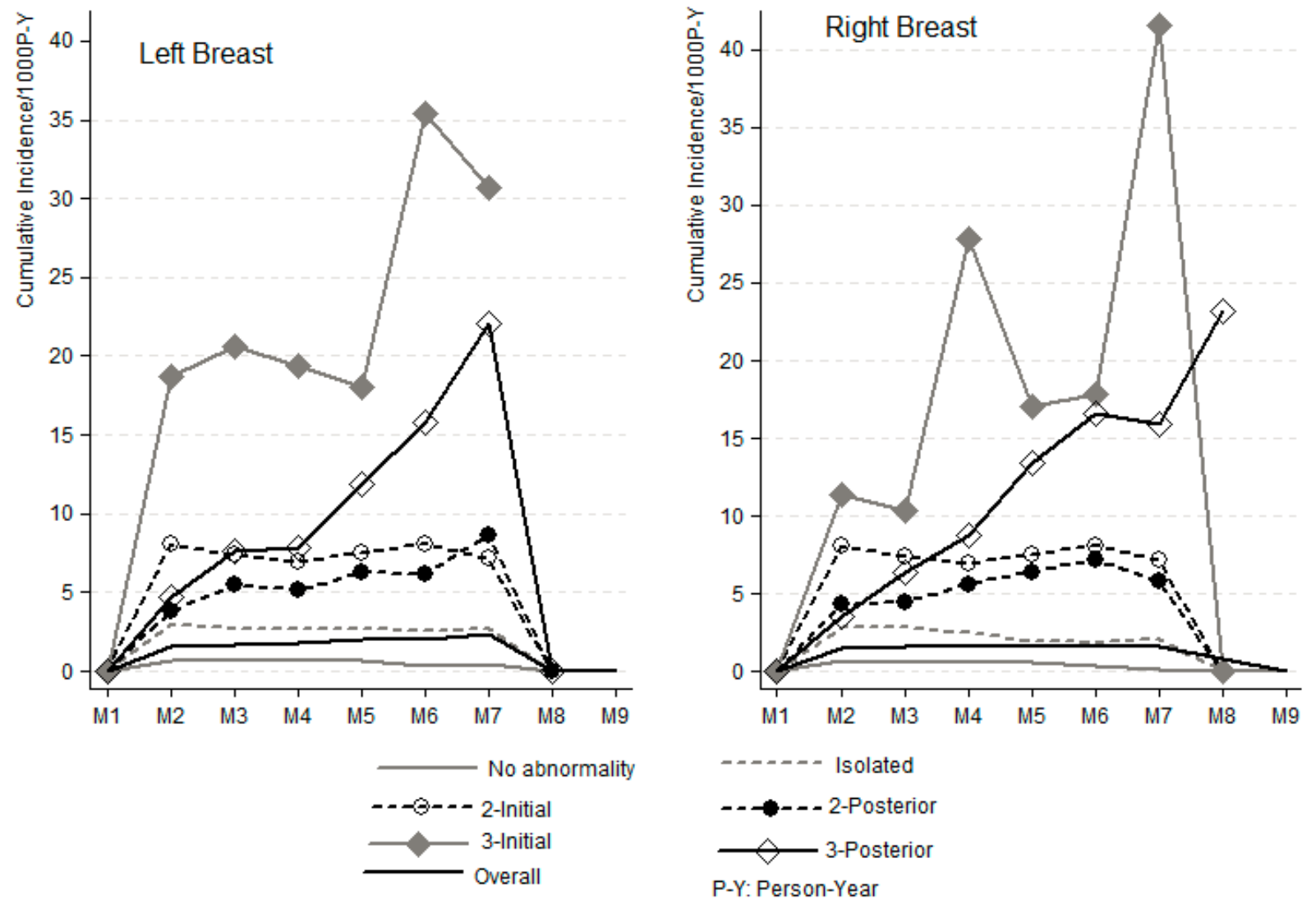

Figure 2

Evolution of cumulative incidence according to the concomitance of radiological abnormalities in the left and right breasts and according to the rank of the screening mammogram (M). No abnormality (if no abnormality in the breast concerned); 1-isolated (1 isolated sign); 2-Initial (2 abnormalities in initial association); 2-posterior (2 abnormalities in posterior association); 3-Initial ( $\geq 3$ abnormalities in initial association); 3-posterior ( $\geq 3$ abnormalities in posterior association); Overall (Sample Cumulative Incidence). 